\title{
PENGARUH HIGH PERFORMANCE WORK SYSTEM (HPWS) DAN KONFLIK PERAN TERHADAP KEPUASAN KERJA
}

\author{
Alifa Nur Maulidina \\ Universitas Negeri Surabaya \\ Alifa.17080574105@mhs.unesa.ac.id \\ Agus Frianto \\ Universitas Negeri Surabaya \\ Agusfrianto@unesa.ac.id
}

\begin{abstract}
The purpose of this research is to study the impact of the High-Performance Work System (HPWS) and role conflict on job satisfaction at PT Temprina Media Grafika, Nganjuk Branch. The sampling technique used was nonprobability sampling - this study uses questionnaires distributed to 40 office employees who worked at PT Temprina Media Grafika Nganjuk. The statistical analysis used in this study was multiple linear tests using SPSS. The results of data testing indicate that HPWS has a significant positive relationship with job satisfaction. This shows that the practice of HPWS in the company is going well, and the level of perceived job satisfaction has also increased. As well as role conflict has a significant negative relationship with job satisfaction. The data test results show that role conflicts that occur within the company will result in a decrease in job satisfaction felt by employees.
\end{abstract}

Keyword :HPWS; job satisfaction; role conflict

\section{PENDAHULUAN}

Persaingan industri saat ini semakin menunjukkan peningkatan sangat pesat, banyak ditemukan permasalahan yang dapat menimbulkan kegagalan usaha. Kegagalan usaha tersebut dapat diatasi dengan memersiapkan karyawan atau sumber daya manusia yang unggul dan baik (Irawati \& Carollina, 2017). Suatu manajemen perusahaan dapat dikatakan berhasil dilihat dari keadaan karyawan atau SDM yang bekerja.Perusahaan sering menghadapi permasalahan SDM yang terkadang menjadi penghambat pencapaian tujuan perusahaan. Apabila sumber daya manusia dalam melaksanakan pekerjaannya berjalan secara baik dan efektif, keberhasilan berjalannya perusahaan juga akan efektif. Bisa dikatakan keberhasilan suatu perusahaan dapat dilihat dari kinerja karyawannya (Lukito \& Alriani, 2018). Selama 20 tahun terakhir, literatur yang berkembang telah merumuskan tentang cara-cara di mana praktik sumber daya manusia (SDM) berdampak positif pada kinerja organisasi, atau garis bawah perusahaan. Seringkali diasumsikan, dan dipertanyakan, bahwa kumpulan praktik SDM akan secara otomatis meningkatkan kinerja untuk organisasi dan karyawan (Heffernan \& Dundon, 2016).

High Performance Work System (HPWS) dianggap sebagai sarana untuk meningkatkan motivasi, kompetensi, dan kinerja karyawan. HPWS mencakup serangkaian praktik SDM yang terpisah namun saling berhubungan yang dapat meningkatkan daya saing karyawan, termasuk penugasan kerja yang fleksibel dan pemberdayaan kerja yang memadai, prosedur rekrutmen dan seleksi yang ketat, pelatihan dan pengembangan ekstensif, penilaian kinerja berdasarkan prestasi, dan kompensasi kompetitif dan upah tinggi (Chen et al., 2016). Penelitian-penelitian sebelumnya telah merumuskan dan mengusulkan konseptualisasi HPWS terutama berdasarkan tampilan sistem karena HPWS dapat menciptakan efeksinergis yang saling menguatkan (Zhang et al., 2018). Namun Fan et al., (2018) menunjukkan HPWS menimbulkan hasil yang bertentangan bagi karyawan dan pemberi kerja. Mereka berinvestasi pada karyawan dengan menawarkan otonomi dan fleksibilitas di tempat kerja, HPWS mengomunikasikan ekspektasi organisasi untuk upaya ekstra dari karyawannya. Dengan demikian, dalam praktik HPWS, karyawan mungkin dihadapkan pada beban kerja yang berlebihan, kecepatan kerja yang tinggi, dan 
Alifa Nur Maulidina \& Agus Frianto. Pengaruh High-Performance Work System (HPWS) dan Konflik Peran terhadap Kepuasan Kerja

tenggat waktu yang ketat serta merasa bahwa mereka terpaksa mengintensifkan pekerjaannya untuk memenuhi kepentingan organisasi.Faktor-faktor yang memengaruhi HPWS antara lain tim kerja yang dapat mengatur dirinya sendiri, employee involvement yang merupakan aspek penting dalam meningkatkan efektivitas organisasi karena merupakan sistem yang mendorong karyawan untuk menggunakan pengalaman dan keahliannya dalam memberikan saran dan informasi yang berkaitan dengan masalah di area kerja mereka (Wulandari et al., 2020).

Tuntutan atas kinerja karyawan akan semakin tinggi seiring berkembangnya sebuah perusahaan. Tingginya tuntutan perusahaan tersebut terhadap karyawan akan memicu timbulnya konflik. Terjadinya konflik diakibatkan oleh adanya perbedaan di antara dua orang atau lebih. Contohnya perbedaaan pendapat, pandangan, tujuan, dan perbedaan lainnya yang muncul antar individu, kelompok, maupun organisasi (Kuncoro et al., 2018). Definisi konflik peran adalah suatu situasi ketika seseorang menghadapi pengharapan peran yang berlawanan. Kemunculan konflik peran ketika individu merasa memenuhi tuntutan satu peran akan menyebabkan dirinya tidak mampu memenuhi tuntutan peran lainnya (Kusriyani \& Magdalena, 2016). Konflik peran bisa dikatakan sebagai gejala psikologis yang dapat menimbulkan rasa tidak nyaman dan menurunkan motivasi kerja.Konflik peran dapat menunjukkan sisi peran positif (fungsional) dan juga negatif (disfungsional). Hal ini berarti, konflik harus diatasi dengan sebaik-baiknya, karena dua sisi positif dan negatifnya dapat mempengaruhi dalam organisasi mencapai tujuannya (Nur et al., 2016). Konflik peran dan ambiguitas peran sering kali dikaitkan dengan hasil yang tidak diinginkan baik bagi anggota individu maupun organisasi secara luas. Mereka dapat menyebabkan ketidakpuasan dengan peran, realitas yang terdistorsi, kepuasan menurun, efektivitas organisasi menurun, kecemasan, komitmen dan kinerja yang lebih rendah (Ebbers \& Wijnberg, 2017).

Perusahaan tidak hanya menginginkan karyawan yang cakap dan terampil, tetapi juga memiliki kemauan untuk berkembang guna mencapai hasil kerja yang optimal. Hasil optimal tersebut dapat dicapai dengan memenuhi hak-hak kerja dari karyawan yang akan menunjang rasa kepuasan kerja (Murtani, 2017). Kepuasan kerja adalah perasaan senang atau tidaknya sebuah pekerjaan, yang ditunjukkan dengan kesesuaian antara harapan kerja dan manfaat yang diterima dari perusahaan (Ridho \& Susanti, 2019). Hal-hal yang mencakup dalam kepuasan kerja seperti kondisi dan perilaku seseorang. Kepuasan kerjatidak terlihat secara nyata, tetapi dapat dilihat melalui hasil kerja seseorang. Kepuasan kerja sangat penting untuk mendorong seorang karyawan untuk bekerja dengan lebih produktif (Bahri et al., 2017). Sikap seseorang atau karyawan terhadap pekerjaannya merupakan cerminan tentang perasaan dan pengalaman menyenangkan maupun tidak dalam bekerja dan harapannya terhadap pekerjaan tersebut yang memberi kepuasan bagi seseorang tersebut. Ketidakpuasan akan muncul ketika seorang karyawan merasa tidak senang mengerjakan suatu pekerjaan (Astuti \& Iverizkinawati, 2018).

Beberapa penelitian menunjukkan hasil positif signifikan seperti Chathurika, (2016), Rahmatullah \& Siddiqui, (2019), dan Maung, (2020), terdapat pengaruh positif yang signifikan dari HPWS terhadap kepuasan kerja karyawan. Widiasari \& Budiono,( 2016), Maoe et al., (2016), dan Palomino \& Frezatti, (2016) menyatakan bahwa konflik peran memiliki pengaruh negatif signifikan terhadap kepuasan kerja. Tetapi berbeda dengan penelitian yang dilakukan oleh Juwita \& Arintika, (2018), bahwa konflik peran berpengaruh secara positif signifikan terhadap kepuasan kerja.

Penelitian ini bermaksud untuk melihat pengaruh dari HPWS dan konflik peran terhadap kepuasan kerja pada karyawan di PT Temprina Media Grafika Cabang Nganjuk. Menurut hasil wawancara dengan HRD, keadaan pandemi saat ini menyebabkan perusahaan melakukan pengurangan karyawan untuk efisiensi perusahaan. Hal ini menyebabkan adanya perubahan sistem kerja. Perusahaan menuntut kinerja yang tinggi pada karyawan sehingga mereka memiliki beban kerja 2 kali lipat dan terkadang memiliki peran atau tanggung jawab yang berlipat. Sistem kerja berkinerja tinggi cukup diterapkan dengan baik di perusahaan. Contohnya seperti jaminan keselamatan dan kesehatan karyawan cukup jelas, sistem kompensasi dan gaji cukup jelas meskipun beberapa karyawan merasa perlu peningkatan upah seiring 
peningkatan beban kerja. Sistem rekruitmen karyawan di perusahaan dilakukan secara terbuka, adil, dan jelas. Training karyawan tidak terlalu sering dilakukan, hal ini menjadi masalah bagi karyawan yang ingin meningkatkan skill dalam bekerja. Hubungan antar karyawan sangat terbuka, di manasesama karyawan terbuka untuk berdiskusi tanpa memandang jabatan atau posisinya. Hal ini mendorong karyawan memiliki kepuasan kerja yang tinggi. Sedangkan konflik peran yang terjadi di perusahaan muncul karena adanya pengurangan karyawan membuat beberapa karyawan memiliki tugas ganda atau lebih. Pekerjaan tersebut bisa sangat berbeda antar satu sama lain. Selain itu perubahan peran atau tuga juga mempengaruhi kinerja karyawan. Beberapa karayawan merasa pekerjaannya yang baru tidak sesuai dengan bidang mereka, sebagian yang lain merasa hal itu wajar terjadi sebagai bagian dari pekerjaannya. (Temprina Media Grafika, 2020). Berdasarkan fenomena tersebut, penelitian ini bertujuan untuk menemukan pengaruh HPWS dan konflik peran terhadap kepuasan kerja PT. Temprina Media Grafika Cabang Nganjuk.

\section{KAJIAN PUSTAKA DAN PENGEMBANGAN HIPOTESIS}

\section{High Performance Work System (HPWS)}

High performance work system (HPWS) mengutamakan konsistensi internal fungsi perusahaan yang diselaraskan dengan strategi dari perusahaan. HPWS mengarah pada kebijakan yang mempengaruhi perilaku sehingga memberikan dampak pada unit atau organisasi, berbeda dengan praktik HRM yang hanya berfokus pada kinerja. Manfaat diterapkannya HPWS yaitu dapat ditingkatkannya kepuasan kerja dan produktivitas karyawan dapat meningkat serta karyawan lebih mampu membuat keputuasan yang lebih baik (Aristana \&Artana, 2020). HPWS adalah praktik SDM yang dibuat untuk meningkatkan keterampilan, komitmen, dan produktivitas karyawan sehingga menjadi sumber keunggulan kompetitif (Ghautama, 2018). HPWS mencakup prosedur rekrutmen dan seleksi karyawan yang komprehensif, kompensasi insentif, sistem manajemen kinerja, dan keterlibatan serta pelatihan karyawan yang ekstensif. HPWS yang terdiri dari persyaratan keterampilan yang relatif tinggi, rancangan kerja, dan struktur insentif (Chen et al., 2016).

Berdasarkan teori pertukaran sosial, para praktisi HPWS berharap bahwa HPWS fokus pada penyediaan dukungan untuk pengembangan karyawan dengan memperkaya pekerjaan, meningkatkan keterampilan kerja karyawan, dan mendorong pengambilan keputusan partisipatif. HPWS akan dibalas oleh karyawan melalui peningkatan keterlibatan kerja dan komitmen terhadap organisasi, yang akibatnya mengarah pada kinerja organisasi yang tinggi. Efek dari praktik HPWS pada sikap dan perilaku individu karyawan menunjukkan terdapat hubungan positif dengan komitmen organisasi, kepuasan kerja, dan retensi karyawan. Praktik HPWS secara positif memengaruhi sikap dan perilaku karyawan, termasuk perilaku membantu dan perilaku kewargaan organisasi (Huang et al., 2018). HPWS dianggap menciptakan nilai bagi organisasi dengan mengurangi biaya, meningkatkan produktivitas, serta menciptakan nilai bagi karyawan. Namun, sulit untuk mengukur peningkatan kinerja organisasi, terutama yang berkaitan dengan peningkatan sumber daya manusia, dan banyak penelitian yang dikembangkan seputar HPWS sering kali bervariasi dan kurang peningkatan SDM (Rahmatullah \& Siddiqui, 2019)

Menurut Maung (2020) HPWS dikaitkan dengan kepuasan kerja karyawan dan komitmen afektif.HPWS, pelatihan, penilaian kinerja dan komunikasi difokuskan untuk menciptakan kepuasan kerja dan kinerja karyawan. Diharapkan dengan adanya praktek HPWS dapat memberikan kontribusi terhadap kinerja karyawan melalui kepuasan kerja. Ketika praktik kerja berkinerja tinggi sejalan dengan persyaratan karyawan, tingkat kinerja karyawan tertinggi akan menjadi hasilnya. Banyak dari praktik HPWS individu dan kumpulan praktik HPWS telah ditemukan memiliki hubungan positif dengan kepuasan kerja.Praktik HPWS yang meningkatkan pemberdayaan memiliki hubungan positif dengan kepuasan kerja baik ketika diperiksa secara individu maupun dalam kelompok. Berkenaan dengan praktik HPWS peningkat 
Alifa Nur Maulidina \& Agus Frianto. Pengaruh High-Performance Work System (HPWS) dan Konflik Peran terhadap Kepuasan Kerja

motivasi, penelitian menunjukkan bahwa penilaian kinerja formal yang mengandung aspek motivasi berhubungan positif dengan kepuasan kerja (Chowhan et al., 2016).

Penggunaan HPWS oleh organisasi mendukung koordinasi relasional di antara karyawan dan selanjutnya memengaruhi hasil organisasi dan karyawan seperti kualitas, efisiensi, dan kepuasan kerja. Ini memberikan gagasan bahwa koordinasi relasional yang dihasilkan dari penggunaan HPWS mungkin penting untuk memutuskan apakah ada hasil positif karyawan yang muncul dari proses pertukaran sosial di tempat kerja. Alasan mengapa HPWS memprediksi kepuasan kerja adalah karena karyawan mungkin merasa bahwa penggunaan HPWS oleh organisasi memberi mereka kesempatan untuk mengembangkan hubungan di tempat kerja. Konsekuensinya, persepsi ini dapat memancing kepuasan kerja karyawan (Haider et al., 2020). Indikator-indikator yang digunakan dalam penelitian ini menurut Ghautama, (2018) meliputi: employee security, menunjukkan bagaimana perasaan karyawan tentang keamanan dan keselamatan kerja. Selain itu, untuk mengetahui bagaimana perusahaan memberi jaminan kerja bagi kayawan. Selective staffing, melihat sejauh mana karyawan mengetahui mekanisme perekrutan dan seleksi dari perusahaan apakah berjalan secara baik dan ketat. Comprehensive training, melihat bagaimana perusahaan melakukan program pelatihan untuk pengembangan karyawan. Selainitu, juga mengukur pandangan karyawan terhadap kemauan perusahaan mengembangkan sumber daya berdasarkan keterampilan dan pengetahuan. Reduced status differentiation, menunjukkan bagaimana karyawan melihat perbedaan status antar posisi. Mencerminkan juga bagaimana hubungan antar karyawan, dan karyawan dengan pimpinan. Competitive compensation and benefits, indikator ini melihat pada sejauh mana karyawan merasa gaji dan tunjangan mereka kompetitif. Selain itu, juga melihat bagaimana sistem kompensasi perusahaan berlaku. Kinerja karyawan, hasil yang diperoleh dari pekerjaan yang dilakukan oleh seorang karyawan yang sudah terencana dengan batas waktu dan tempat yang ditentukan oleh karyawan tersebut

\section{Konflik Peran}

Konflik peran merupakan keadaan di mana seseorang menghadapi perbedaan harapan terhadap peran yang berlawanan.Konflik peran timbul ketika individu menemukan bahwa memenuhi tuntutan satu peran membuat dirinya kesulitan memenuhituntutan peran yang lainnya (Kusriyani \&Magdalena, 2016). Konflik didefinisikan sebagai "kondisi di mana seseorang menghadapi harapan peran yang bertentangan". Jadi, konflik tersebut muncul apabila seseorang yang berada dalam suatu peran dihadapakan pada situasi tuntutan atau keharusan melakukan pekerjaan yang berbeda dengan keinginan atau bidang kerjanya (Hartini, 2017). Secara operasional, konflik peran dapat dimengerti dalam istilah: kesesuaian/ketidaksesuaian antara: standar atau nilai dan perilaku yang ditentukan untuk sebuah peran; waktu, sumber daya atau kemampuan dan perilaku dalam melaksanakan suatu peran; berbagai peran yang harus dijalankan oleh seorang eksekutif tunggal, dan berbagai masukan organisasi yang dimasukkan ke dalam kebijakan, aturan, dan saran dari orang-orang yang terkait dengan peran eksekutif yang sedang menjabat (Palomino \& Frezatti, 2016) .

Definisi konflik peran adalah kondisi di mana seorang individu menghadapi harapan-harapan peran yang berlainan. Keadaan ini muncul ketika seorang individu untuk memenuhi tuntutan satu peran, membuat dirinyakesulitan untuk memenuhi peran lain. Hal ini menyebabkan tuntutan pekerjaan dapat melebihi kapasitas sehingga berakibat kesadaran danpengertian individu berkurang (Edwy et al., 2016). Penyebab dari munculnya konflik dapat diketahui dari adanya tujuan yang ingin diperoleh, rasa ego manusia, kebutuhan seorang individu, perbedaan pendapat, kesalahpahaman, perasaan yang dirugikan.Berbagai macam jenis peranan yang dilakukan oleh seorang individu dalam satu posisi juga akan memicu adanya konflik peran (Maoe et al., 2016). Jika seseorang memiliki dua peran atau lebih dalam satu waktu yang sama, maka seseorang tersebut akan mengalami konflik peran. Konflik peran dikatakan juga merupakan konflik karena seseorang memerluas peran yang bertentangan. Konflik peran dapat dikatakan sebagai salah satugejala psikologis yang dialami seseorang yang menimbulkan rasa tidak nyaman dan berpotensi menyebabkan motivasi dan kinerja kerja seseorang menurun (Amirullah, 2018). 
Widiasari \& Budiono, (2016) mengungkapkan konflik peran memiliki 6 tipe, yaitu: konflik intra pengirim (intrasender conflict), ketika tugas atau pekerjaan yang diberikan pada individu tidak sesuai satu sama lainnya akan menyebabkan adanya konflik. Konflik antar pengirim (intersender conflict), adanya perbedaan pemikiran satu orang atau kelompok dengan pemikiran orang atau kelompok lain. Konflik orang-peranan (person-role conflict), harapan peran dalam menyelesaikan pekerjaan tidak sama dengan kebutuhan individu tersebut. Konflik yang muncul karena beban kerja berlebih (in role overload conflict), adanya keterbatasan waktu sehingga seorang individu tidak mampu menyelesaikan pekerjaan dengan tepat waktu atau sesuai batas yang ditetapkan. Ambiguitas peran, ketika seorang karyawan kekurangan informasi yang lengkap tentang tanggung jawabnya. Konflik antar peran (inter-role conflict), seorang individu melakukan bermacam-macam peran dengan tuntutan yang tidak sama antar satu sama lain.

Konflik peran merupakan bagian integral dari lingkungan kerja, dan fenomena nyata terkait dengan orang yang bekerja di lingkungan kerja yang sama setiap hari (Rovithis et al., 2017). Penelitian ini menggunakan indikator konflik peran menurut Yasa, (2017) adalah sumber daya manusia yang tidak mencukupi untuk menyelesaikan pekerjaan dan melakukan pekerjaan dengan cara yang berbeda; menyelesaikan tugas dengan cara mengesampingkan aturan dan menerima pekerjaan dari dua pihak atau lebih yang tidak sesuai satu sama lain; pekerjaan yang dapat diterima oleh satu pihak tetapi pihak lain tidak menerima dan melakukan pekerjaan yang tidak penting; dan mendapat arahan dan perintah kerja yang tidak jelas.

\section{Kepuasan Kerja}

Kepuasan kerja menggambarkan seberapa puas seseorang dengan pekerjaannya. Kepuasan kerja dianggap sebagai keadaan di mana munculnya rasa senang dan positif yang berasal dari penilaian pekerjaan dan pengalaman kerja seseorang (Pang \& Lu, 2018). Kepuasan kerja adalah perpaduan antara keadaan mental, fisiologis, dan alami yang membuat seseorang dengan jujur mengatakan bahwa saya puas dengan pekerjaan saya. Kepuasan kerja dicirikan sebagai perbedaan antara ukuran hadiah yang didapat pekerja dan jumlah yang mereka percayai yang seharusnya didapatkan (Rahman et al., 2017). Kepuasan kerja adalah akumulasi dari emosi yang terhubungan dengan pekerjaan yang dilakukan. Ketika seseorang percaya bahwa nilai atau hasil mereka dihargai, secara sukarela mereka akan mengembangkan sikap positif dan merasakan kepuasan kerja. Memastikan penilaian kinerja, sistem penghargaan, dan tunjangan dengan baik dan sesuai memungkinkan peningkatan kepuasan kerja (Kianto et al., 2016).

Dimensi kepuasan kerja erat dihubungkan dengan hal-hal seperti turn over, tingkat absensi, umur, tingkat pekerjaan, dan ukuran organisasi perusahaan. Ukuran dimensi kepuasan kerja relatif sama antar satu organisasi dengan organisasi lainnya (Arda, 2017). Kepuasan kerja dipengaruhi oleh banyak faktor, tetapi faktor-faktor tersebut bergantung pada pribadi masing-masing karyawan. Berikut faktor-faktor yang mempengaruhi kepuasan kerja seperti faktor psikologis, faktor sosial, faktor fisik, faktor finansial. Gagasan lain mengungkapkan bahwa faktor pada diri karyawan dan faktor pekerjaannya juga mempengaruhi kepuasan kerja (Harahap, 2019). Aruan \& Fakhri, (2015) mengungkapkan empat cara karyawan menunjukkan ketidakpuasan kerjanya meliputi: keluar (exit), yaitu memutuskan untuk berhenti dari pekerjaan atau mencari pekerjaan lain; menyuarakan (voice), yaitu membicarakan setiap masalah pada atasan dan mencoba memberi saran untuk penyelesaian masalah secara aktif; mengabaikan (neglect), yaitu melakukan tindakan yang melanggar aturan pekerjaan, seperti datang terlambat, sering melakukan absen, tidak bekerja dengan maksimal, sering melakukan kesalahan. Penelitian ini akan menggunakan indikator-indikator kepuasan kerja menurut Harahap et al., (2019) yaitu kondisi pekerjaan; supervise; organisasi dan manajemen; promosi; gaji; dan rekan kerja

\section{Hubungan Antara Variabel}

Sahani, (2016) menunjukkan pengaruh yang kuat dan positif HPWS terhadap kepuasan kerja karyawan di dua bank swasta di distrik Colombo. Menurut Maung, (2020) semua variabel laten (pelatihan, penilaian 
Alifa Nur Maulidina \& Agus Frianto. Pengaruh High-Performance Work System (HPWS) dan Konflik Peran terhadap Kepuasan Kerja

kinerja dan komunikasi) memiliki pengaruh langsung yang signifikan terhadap kepuasan kerja. Semua variabel tersebut penting bagi karyawan untuk meningkatkan kepuasan mereka yang menunjukkan bahwa studi ini terutama difokuskan pada efek HPWS terhadap kepuasan kerja dan kinerja karyawan. Rahmatullah \& Siddiqui, (2019) menunjukkan bahwa terdapat pengaruh yang signifikan positif antara HPWS dengan kepuasan kerja. Penelitian Chowhan et al., (2016) terhadap pekerja imigran, menunjukkan bahwa praktik HPWS individu tidak memoderasi atau berhubungan dengan pengaruh kepuasan kerja tetapi jika praktik HPWS secara keseluruhan memberi pengaruh positif terhadap kepuasan kerja. Chowhan et al., (2016) juga mengatakan ketika praktik HPWS yang memiliki penilaian kinerja formal, penilaian yang memengaruhi penghargaan, promosi, memiliki paket tunjangan non-upah, dan praktik pembayaran-untuk-kinerja dibentuk bersama untuk menciptakan paket HPWS yang meningkatkan motivasi, hal itu secara positif memengaruhi kepuasan kerja. HPWS membangun lingkungan yang saling menguntungkan di mana perusahaan berinvestasi pada karyawan mereka, sebagai imbalannya karyawan akan merespon dengan sikap positif terhadap pekerjaan dan organisasi (Rahmatullah \& Siddiqui, 2019)

H1 : HPWS berpengaruh positif signifikan terhadap kepuasan kerja.

Widiasari \& Budiono, (2016), menunjukkan variabel konflik peran berpengaruh negatif signifikan terhadap kepuasan kerja. Artinya semakin tinggi konflik akan menurunkan kepuasan kerja dari karyawan. Palomino \& Frezatti, (2016) menunjukkan hasil tidak adanya penolakan dari kedua hipotesis studi yang diajukan.terlihat bahwa konflik peran dirasakan oleh pengontrol Brasil dari sampel berpengaruh negatif terhadap kepuasan kerja mereka. Maoe et al., (2016) menunjukkan bahwa konflik peran memiliki pengaruh negatif siginifikan terhadap kepuasan kerja. Hal ini berarti bahwa semakin tinggi konflik peran maka kepuasan kerja semakin rendah, demikian pula sebaliknya. Juwita \& Arintika, (2018) menyatakan bahwa konflik peran memiliki pengaruh positif signifikan terhadap kepuasan kerja. Di mana karyawan merasa bahwa adanya konflik peran masih cukup setara dengan harapan yang mereka miliki atas pekerjaannya. Para karyawan beranggapan bahwa adanya konflik peran sebagai risiko dari pekerjaan, dan sudah sewajarnya terjadi.Edwy et al., (2016) meneliti para auditor di kantor akuntan publik, menunjukkan hasil yang berbeda yaitu konflik peran tidak memiliki pengaruh terhadap kepuasan kerja. Hal ini disebabkan karena hanya beberapa karyawan yang merasakan adanya konflik peran dan yang lainnya merasa konflik peran adalah resiko atas pekerjaan yang mereka jalani.

H2 : Konflik peran berpengaruh negatif signifikan terhadap kepuasan kerja.

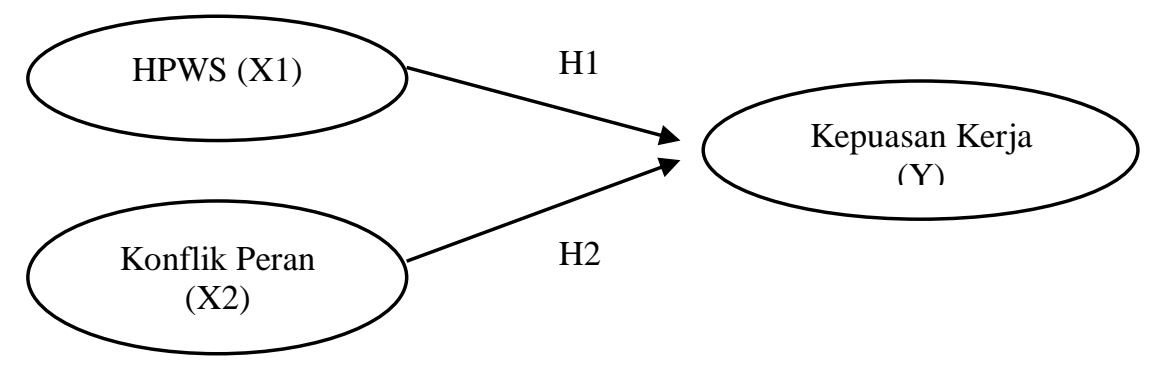

Gambar 1.KERANGKA PENELITAN

\section{METODE PENELITIAN}

Jenis penelitian ini merupakan penelitian kuantitatif dengan menggunakan data primer yang merupakan data hasil observasi langsung dengan objek penelitian dan data sekunder yang berasal dari sumber literasi sebagai pelengkap. Penelitian ini mengunakan variabel HPWS sebagai X1, konflik peran sebagai X2, dan kepuasan kerja sebagai Y. Pengumpulan data tersebut dilakukan dengan metode observasi, wawancara, 
dan kuesioner secara langsung atau offline. Studi kasus pada pengkajian ini dilakukan di PT. Temprina Media Grafika Cabang Nganjuk. Populasi dalam penelitian ini adalah 40 karyawan kantor di bagian HRD, divisi keuangan, divisi marketing, divisi manajemen produksi, divisi administrasi dan umum yang seluruhnya dijadikan sampel penelitian.

Pengambilan sampel menggunakan metode non-probability sampling. Jenis teknik non-probability sampling yang digunakan dalam penelitian ini yaitu sampling judgemental. Skala pengukuran dalam penelitian ini menggunakan skala likert. Rentang skala berawal dari skala 1 (Sangat Tidak Setuju) sampai dengan skala 5 (Sangat Setuju). Data diolah dengan analisis regresi berganda menggunakan program SPSS Statisctic PASW 18.

\section{HASIL DAN PEMBAHASAN}

\section{Hasil Uji Validitas}

Uji validitas bertujuan untuk menguji kelayakan pernyataan dalam angket dengan perbandingan r-hitung dan r-tabel, sehingga dapat mengungkap isi yang akan diukur dengan angket. Ketentuan r- tabel jika jumlah responden 33 untuk uji validitas dengan tingkat kesalahan 5\% $(0,05)$ adalah 0,355 yang diperoleh dari $D F=N-2$, sehingga $D F=33-2=31$. Data dikatakan valid jika $\mathrm{r}$ hitung lebih besar atau $>\mathrm{r}$ tabel. Hasil validitas variabel HPWS atau X1 sebanyak 12 poin pernyataan, semua pernyataan terbukti valid. Hasil uji validitas variabel konflik peran atau X2 sebanyak 12 poin pernyataan, semua terbukti valid. Hail uji validitas variabel kepuasan kerja atau Y terdapat 14 poin pernyataan yang valid.

\section{Hasil Uji Reliabilitas}

Uji reliabilitas bertujuan untuk memastikan apakah kuesioner penelitian yang akan dipergunakan untuk mengumpulkan data variabel penelitian reliabel atau tidak. Kuesioner dikatakan reliabel jika kuesioner tersebut dilakukan pengukuran ulang, maka akan mendapatkan hasil yang sama. Hasil uji reliabilitas dapat dilihat dari nilai Cronbach's Alpha. Jika nilai tersebut> 0,70 maka semua item dapat digunakan sebagai alat ukur atau bisa dikatakan konsisten. Nilai Cronbach's Alpha untuk variabel X1 adalah 0,895, nilai variabel X2 adalah 0,923 dan nilai untuk variabel Y adalah 0,880.

\section{Hasil Uji Asumsi Klasik}

\section{Tabel 1. \\ UJI ASUMSI KLASIK}

\begin{tabular}{lcccc}
\hline \multicolumn{1}{c}{ Variabel } & Normalitas & Autokorelasi & \multicolumn{2}{c}{ Multikolinieritas } \\
& Sig. & $\boldsymbol{D W}$ & Tolerance & VIF \\
\hline \multirow{3}{*}{ HPWS } &, 701 & 2,080 & & \\
Konflik Peran & & &, 963 & 1,038 \\
& & &, 963 & 1,038 \\
\hline
\end{tabular}

Sumber : Output SPSS (2021, data diolah)

Uji Asumsi Klasik meliputi uji normalitas, uji multikolinieritas, uji heteroskedastisitas, dan uji autokorelasi. Hasil uji normalitas menggunakan metode Kolmogorov-smirnov (KS) ditunjukkan pada tabel 1 nilai signifikansi 0,701 atau $>0,05$. Hal ini berarti bahwa data terdistribusi normal. Uji multikolinieritas menunjukkan hasil nilai tolerance 0,963 atau > 0,1 dan nilai VIF 1,038 atau < 10. Hal ini berarti bahwa tidak terdapat multikolinieritas pada data yang diuji. Uji heteroskedastisitas yang menggunakan output Scatterplots menunjukkan titik-titik data tidak berkumpul pada satu area, menyebar di sekitar angka 0 , dan tidak membentuk pola. Hal ini berarti bahwa tidak terjadi heteroskedastitas pada 
Alifa Nur Maulidina \& Agus Frianto. Pengaruh High-Performance Work System (HPWS) dan Konflik Peran terhadap Kepuasan Kerja

data yang diuji. Uji autokorelasi yang menggunakan Durbin-watson (DW) memeroleh nilai d $=2,080$ dengan derajat kepercayaan 5\% (0.05), jumlah variabel independen $(\mathrm{k})=2$, dan total responden $(\mathrm{n})=40$ yang dimasukkan dalam persamaan $\mathrm{du}<\mathrm{d}<4$-du menjadi $1,6000<2,080<2,4000$. Dari hasil persamaan tersebut, tidak ditemukan adanya autokorelasi.

\section{Hasil Uji Hipotesis}

Uji hipotesis dilakukan untuk membuktikan hipotesis diterima arau tidak diterima.Hasil uji determinasi $\left(\mathrm{R}^{2}\right)$ sebesar 0,303 atau 30,3\% yang berarti kemampuan yang dimiliki model dalam menjelaskan variabel HPWS dan konflik peran untuk menerangkan variabel dependen sebesar 30,3\%, sedangkan sisanya $69,7 \%$ dijelaskan oleh faktor lain di luar model penelitian.

Berdasarkan hasil uji regresi linier berganda dapat ditunjukkan persamaan (1) dan (2).

$Y=\alpha+\beta 1 X 2+\beta 2 X 2+\beta n X n+e$.

Kepuasan kerja $=58,790+0,431 X 1-0,512 X 2+e$.

Jika nilai koefisien regresi variabel HPWS dan konflik peran 0, maka terjadi kenaikan kepuasan kerja sebesar 58,790. Jikanilai koefisien regresi, yaitu 0,431 dari variabel HPWS kemudian dapat dibuat sebuah asumsi dengan pernyataan bila terjadi peningkatan senilai 1 dari variabel HPWS maka terjadi kenaikan senilai 0,431 dari nilai variabel kepuasan kerja. Koefisien bernilai positif menunjukkan adanya hubungan positif antara HPWS dengan kepuasan kerja. Begitu juga ketika nilai koefisien regresi variabel konflik peran yaitu $-0,512$ kemudian dapat diasumsikan bila terjadi peningkatan senilai 1 dari variabel konflik peran maka terjadi penurunan senilai 0,512 dari nilai variabel kepuasan kerja. Koefisien bernilai negatif menunjukkan adanya hubungan negatif antara konflik peran dengan kepuasan kerja.

Hasil uji t menjelaskan bahwa secara parsial variabel HPWS memiliki pengaruh signifikan positif terhadap variabel kepuasan kerja. Hal ini dapat dilihat dari nilai uji t variabel HPWS yaitu nilai t-hitung 4,055> 2,026 t-tabel dan nilai signifikan 0,000 atau $<0,05$. Variabel konflik peran memiliki pengaruh signifikan negatif terhadap variabel kepuasan kerja. Dibuktikan dengan nilai t-hitung $-2,326<-2,026 \mathrm{t}-$ tabel dan nilai signifikan 0,026 atau $<0,05$.

Tabel 2.

HASIL UJI REGRESI LINIER BERGANDA

\begin{tabular}{lcccc}
\hline \multicolumn{1}{c}{ Variabel } & $\begin{array}{c}\text { Determinasi }\left(\mathbf{R}^{2}\right) \\
\text { Adj. } \boldsymbol{R} \text { Square }\end{array}$ & $\begin{array}{c}\text { Coefficient } \\
\text { B }\end{array}$ & \multicolumn{2}{c}{ Uji T } \\
&, 303 & & & Sig. \\
\hline Constant) & & 58,790 & 5,278 &, 000 \\
HPWS & & -431 & 4,055 &, 000 \\
Konflik Peran &,- 512 & $-2,326$ &, 026 \\
Dependent Variable $:$ Produktivitas Kerja & & & \\
\hline
\end{tabular}

Sumber :Output SPSS (2021, data diolah)

\section{Pengaruh HPWS terhadap Kepuasan Kerja}

Hasil penelitian, terdapat pengaruh signifikan positif HPWS terhadap kepuasan kerja, maka H1 diterima. Hal ini sejalan dengan penelitian Maung, (2020), membuktikan hubungan antara HPWS dan kepuasan kerja. HPWS, (pelatihan, penilaian kinerja dan komunikasi) difokuskan untuk menciptakan kepuasan kerja dan kinerja karyawan.Diharapkan dengan adanya praktik HPWS dapat memberikan kontribusi terhadap kinerja karyawan melalui kepuasan kerja. Sumber daya manusia akan lebih memuaskan 
pekerjaannya melalui pembuatan HPWS menurut departemen. HPWS akan menciptakan karyawan yang sangat terampil, terlibat, dan berdaya yang merasakan nilai-nilai dan menikmati kepuasan kerja yang lebih tinggi dan dengan demikian, ada hubungan positif yang kuat antara HPWS dan kepuasan kerja. Menurut Haider et al., (2020) alasan mengapa HPWS memprediksi kepuasan kerja adalah karena karyawan mungkin merasa bahwa penggunaan HPWS oleh organisasi memberi mereka kesempatan untuk mengembangkan hubungan di tempat kerja. Konsekuensinya, persepsi ini dapat memancing kepuasan kerja karyawan. Alasan lain mengapa HPWS memprediksi kepuasan kerja karyawan adalah karena HPWS dapat memengaruhi persepsi karyawan bahwa mereka bekerja di lingkungan psikologis yang aman yang ditandai dengan hubungan dan komunikasi berkualitas tinggi.

Behravesh et al., (2018) juga menyatakan adanya hubungan positif antara HPWS dengan kepuasan kerja.Hubungan positif langsung antara HPWS dan kepuasan kerja konsisten dengan teori COR, yang menunjukkan bahwa sumber daya yang berbeda seperti dukungan sosial, iklim kerja tim, pelatihan, umpan balik, keamanan kerja dan promosi mempengaruhi sikap karyawan seperti kepuasan kerja. Ini menegaskan bahwa HPWS meningkatkan kepuasan dengan menciptakan pengalaman yang menyenangkan seperti memberikan dukungan sosial, lebih banyak jaminan finansial atau pekerjaan, peluang untuk promosi dan penghargaan. Rahmatullah \& Siddiqui, (2019) menyebutkan bahwa HPWS membangun lingkungan yang saling menguntungkan di mana perusahaan berinvestasi pada karyawan mereka sebagai imbalannya karyawan akan merespon dengan sikap positif terhadap pekerjaan dan organisasi. Tidak seperti pengendalian manajemen SDM, praktik HPWS menganggap kepuasan kebutuhan karyawan menjadi yang paling signifikan. Selain itu, HPWS yang diterapkan oleh organisasi dapat meningkatkan persepsi karyawan dan orang tempat mereka bekerja, yang menghasilkan kepuasan yang lebih besar.

Hasil yang diperoleh melalui pengujian, wawancara, dan observasi di PT Temprina Media Grafika Cabang Nganjuk menunjukkan bahwa praktik HPWS berjalan cukup baik. Perusahaan cukup baik dalam merancang praktik HPWS yang diterapkan dalam sistem kerja karyawan. Perusahaan sudah cukup baik dalam berinvestasi terhadap karyawan. Begitu juga dengan karyawan yang cukup merasakan dampak dari adanya praktik HPWS yang ada. Praktik HPWS yang dilakukan oleh perusahaan seperti sistem K3 yang jelas dan terlaksana, jaminan kesehatan yang diperoleh oleh setiap karyawan, sistem rekruitmen berjalan secara terbuka dan sistematis, pemberian upah lembur dan gaji yang tepat waktu dan sesuai, sistem lembur, izin, dan cuti yang jelas dan terbuka, lingkungan kerja yang dinamis, hubungan antar karyawan dan atasan yang terbuka tidak memandang status jabatan atau senioritas, kinerja karyawan yang berjalan dengan baik, evaluasi kinerja karyawan yang teratur, dan training yang disediakan perusahaan untuk karyawan. Sistem kerja yang berjalan seperti ini membuat karyawan cukup merasa puas dengan apa yang diberikan oleh perusahaan meskipun masih terdapat karyawan yang merasa masih perlu adanya peningkatan. Ketika praktik kerja berkinerja tinggi sejalan dengan persyaratan karyawan, tingkat kinerja karyawan tertinggi akan menjadi hasilnya.

\section{Pengaruh Konflik Peran terhadap Kepuasan Kerja}

Konflik peran berpengaruh signifikan negatif terhadap kepuasan kerja, H2 diterima. Pembuktian ini sejalan dengan Maoe et al., (2016) bahwa konflik peran memiliki pengaruh signifikan negatif terhadap kepuasan kerja. Di mana semakin tinggi konflik yang dialami, tingkat kepuasan kerja juga akan menurun. Konflik peran yang dialami akan memengaruhi kepuasan kerja baik menyangkut pekerjaan atau hasil yang diterima karyawan. Bongga \& Susanty, (2018) juga menyatakan bahwa konflik peran berpengaruh signifikan negatif terhadap kepuasan kerja. Di mana konflik peran juga diikuti oleh ambiguitas peran yang menjadi kesatuan dan memberikan pengaruh terhadap kepuasan kerja karyawan. Bongga \& Susanty, (2018) juga mengatakan jika perusahaan ingin meningkatkan tingkat kepuasan kerja karyawannya, maka perusahaan harus menurunkan tingkat ambiguitas peran. Hal ini tidak berarti mengabaikan konflik peran karena konflik peran juga secara simultan berpengaruh negatif sebagai ketidakjelasan peran terhadap 
Alifa Nur Maulidina \& Agus Frianto. Pengaruh High-Performance Work System (HPWS) dan Konflik Peran terhadap Kepuasan Kerja

kepuasan kerja. Widarni (2017) menyatakan bahwa adanya konflik peran memiliki pengaruh negatif terhadap kepuasan kerja. Di mana semakin tinggi konflik akan menurunkan kinerja karyawan dan memicu keinginan untuk keluar, izin atau absen bekerja, dan komitmen kerja yang menurun. Hal-hal tersebut akan mengarah pada menurunnya kepuasan kerja karyawan.

Berdasarkan hasil pengujian hipotesis, wawancara, dan observasi yang dilakukan di PT Temprina Media Grafika Cabang Nganjuk menunjukkan bahwa adanya konflik peran dapat menurunkan tingkat kepuas an kerja karyawan. Meskipun dari hasil penelitian, tingkat pengaruh konflik peran terhadap kepuasan kerja karyawan kecil, hal ini tetap perlu diperhatikan. Konflik peran yang dirasakan karyawan lebih banyak pada adanya tumpang tindih pekerjaan yang berbeda antar satu sama lain atau di luar bidangnya. Selain itu juga beberapa karyawan merasa pekerjaannya tidak sepenuhnya didukung oleh sumber daya perusahaan seperti kurangnya fasilitas yang mendukung. Perubahan jumlah karyawan juga mempengaruhi munculnya konflik peran karena beban kerja yang berubah menjadi dua kali lipat. Keadaan ini membuat harapan atau kepuasan karyawan terhadap pekerjaannya menurun. Tetapi ada pula karyawan yang merasa jika konflik peran yang terjadi adalah risiko atau bagian dari pekerjaannya yang wajar terjadi. Jika perusahaan menginginkan karyawan merasa puas dengan pekerjaan dan hasil yang diperoleh serta memiliki kinerja yang tinggi dan baik, maka diharapkan perusahaan dapat mengurangi terjadinya konflik peran baik antar karyawan ataupun dengan atasan.

\section{KESIMPULAN}

Penelitian ini dapat disimpulkan bahwa HPWS berpengaruh secara positif signifikan terhadap kepuasan kerja karyawan di PT Temprina Media Grafika. Hal ini berarti bahwa semakin tinggi atau baik praktik HPWS akan semakin meningkatkan tingkat kepuasan kerja karyawan. Konflik peran berpengaruh secara negatif signifikan terhadap kepuasan kerja karyawan di PT Temprina Media Grafika. Hal ini berarti semakin tingginya konflik peran yang dialami karyawan akan menurunkan tingkat kepuasan kerja karyawan.

Hasil penelitian ini diharapkan dapat digunakan sebagai masukan atau pertimbangan bagi perusahaan dalam upaya meningkatkan kepuasan kerja karyawan.Hasil penelitian ini juga bisa digunakan untuk melihat bagaimana praktik HPWS dan konflik peran yang terjadi pada karyawan PT Temprina Media Grafika Cabang Nganjuk. Selain itu dapat juga digunakan sebagai masukan untuk merancang strategi dalam menangani permasalahan terkait praktik HPWS dan konflik peran. Pada variabel HPWS, pengadaan training masih dirasa kurang oleh karyawan, maka dari itu disarankan bagi perusahaan untuk lebih sering melaksanakan training untuk meningkatkan skill dan pengetahuan karyawan sehingga meningkatkan pemenuhan harapan atau kepuasan atas pekerjaan mereka. Sebelum menentukan bagaimana training berjalan, sebaiknya perusahaan melakukan survey/pendataan kegiatan training yang diinginkan oleh karyawan, tetapi tetap melihat kebutuhan perusahaan. Pada konflik peran, indikator pekerjaan dengan sumber daya yang kurang dan beban pekerjaan yang berbeda antar stau sama lain atau tidak sesuai dengan bidangnya menjadi indikator yang paling tinggi dirasa oleh karyawan. Perusahaan disarankan untuk sering melakukan diskusi terbuka terkait keluhan atau konflik yang dirasa oleh karyawan. Perusahaan juga diharapkan lebih perhatian terkait pemenuhan sumber daya dukungan untuk aktivitas pekerjaan karyawan. Sistem pembagian pekerjaan disarankan lebih adil di mana sesuai dengan bidang dan keahlian. Jika situasi memaksa untuk seseorang mengambil tugas di luar keahliannya, perusahaan perlu memberikan fasilitas pelatihan atau training untuk persiapan karyawan tersebut.

Penelitian ini memiliki keterbatasan di mana variabel konflik peran belum dapat terlalu menunjukkan dan menjelaskan pengaruhnya terhadap kepuasan kerja karena signifikansinya yang lemah. Disarankan untuk peneliti selanjutnya untuk melakukan penelitian dengan jumlah sampel yang lebih luas dan pada bagian atau departemen lainnya. Pada variabel HPWS terdapat keterbatasan di mana sampel penelitian hanya dilakukan pada karyawan tetap perusahaan. Selain itu, penelitian selanjutnya bisa menggunakan sampel 
karyawan lepas dan kontrak yang ada di perusahaan. Selain itu, penelitian selanjutnya bisa dilakukan pada karyawan di perusahaan yang berbeda bidang dengan perusahaan yang diteliti oleh penulis.

\section{DAFTAR PUSTAKA}

Amirullah, N. (2018). The Mediating Role of Employee Performance: The Effects of Transformational Leadership, Emotional Intelligence and Role Conflict on Job Satisfaction. The International Journal of Engineering and Science (IJES), 7(4), 45-51. https://doi.org/10.31219/osf.io/xt6fe

Arda, M. (2017). Pengaruh Kepuasan Kerja dan Disiplin Kerja terhadap Kinerja Karyawan pada Bank Rakyat Indonesia Cabang Putri Hijau Medan. Jurnal Ilmiah Manajemen Dan Bisnis, 18(1), 45-60. https://doi.org/10.30596/jimb.v18i1.1097

Aristana, I. N., \& Artana, I. W. A. (2020). Indentifikasi High Performance Work System. Journal of Applied Management and Accounting Science (J A M A S), 01(2), 76-91.

Aruan, Q. S., \& Fakhri, M. (2015). Pengaruh Lingkungan Kerja terhadap Kepuasan Kerja Karyawan Lapangan Departemen Grasberg Power Distribution PT. Freeport Indonesia. Modus, 27(2), 141162.

Astuti, R., \& Iverizkinawati. (2018). Pengaruh Kepemimpinan dan Lingkungan Kerja terhadap Kepuasan Kerja Karyawan pada PT. Sarana Agro Nusantara Medan. Jurnal Ilman, 6(1), 26-41.

Bahri, S., \& Chairatun Nisa, Y. (2017). Pengaruh Pengembangan Karir dan Motivasi Kerja Terhadap Kepuasan Kerja Karyawan. Jurnal Ilmiah Manajemen Dan Bisnis, 18(1), 9-15. https://doi.org/10.30596/jimb.v18i1.1395

Behravesh, E., Tanova, C., Abubakar, A. M., Zhang, J., Akhtar, M. N., Bal, P. M., Zhang, Y., \& Talat, U. (2018). Do High-Performance Work Systems Always Help to Retain Employees or Is There A Dark Side? Frontiers in Psychology, 40(APR), 1-13. https://doi.org/10.3389/fpsyg.2018.00586

Bongga, W., \& Susanty, A. I. (2018). The Influence Of Role Conflict And Role Ambiguity on Employee Job Satisfaction of Transportation Companies in Indonesia. International Journal of Supply Chain Management, 7(2), 223-227.

Chathurika. (2016). The Impact of High Performance Work Systems on Job Satisfaction: An Investigation of Executives in Public Sector Banks in Colombo District, Sri Lanka Chathurika,. Journal of Chemical Information and Modeling, 1(1), 1689-1699.

Chen, T.-J., Lin, C.-C., \& Wu, C.-M. (2016). High Performance Work System, Psychological Efficacy, Job Satisfaction and Task Performance in the Hotel Workplace. Open Journal of Social Sciences, 04(07), 76-81. https://doi.org/10.4236/jss.2016.47012

Chowhan, J., Zeytinoglu, I. U., \& Cooke, G. B. (2016). Immigrants and Job Satisfaction: Do High Performance Work Systems Play A Role? Economic and Industrial Democracy, 37(4), 690-715. https://doi.org/10.1177/0143831X14550696

Ebbers, J. J., \& Wijnberg, N. M. (2017). Betwixt And Between: Role Conflict, Role Ambiguity and Role Definition in Project-Based Dual-Leadership Structures. Human Relations, 70(11), 1342-1365. https://doi.org/10.1177/0018726717692852 
Alifa Nur Maulidina \& Agus Frianto. Pengaruh High-Performance Work System (HPWS) dan Konflik Peran terhadap Kepuasan Kerja

Edwy, F., Ratnawati, V., \& Haryani, E. (2016). Pengaruh Komitmen Organisasional, Komitmen Profesional, Motivasi Kerja, Konflik Peran, Ketidakjelasan Peran dan Kelebihan Peran terhadap Kepuasan Kerja Auditor pada Kantor Akuntan Publik di Pekanbaru, Padang dan Batam. Jurnal Online Mahasiswa Fakultas Ekonomi Universitas Riau, 3(1), 163-176.

Fan, X., Liu, Y., \& Zou, X. (2018). Where There is Light, There is Dark: A Dual Process Model of HighPerformance Work Systems in The Eyes of Employees. Frontiers of Business Research in China, 12(1). https://doi.org/10.1186/s11782-018-0042-x

Ghautama, H. (2018). Gender dan Masa Kerja: Mampukah Memoderasi Pengaruh antara HighPerformance Work System terhadap Kinerja Karyawan? Jurnal Ilmu Manajemen (JIM), 7(1), 160171.

Haider, S., De-Pablos-Heredero, C., \& De-Pablos-Heredero, M. (2020). A Three-Wave Longitudinal Study of Moderated Mediation Between High-Performance Work Systems and Employee Job Satisfaction: The Role of Relational Coordination and Peer Justice Climate. Frontiers in Psychology, 11(May), 1-15. https://doi.org/10.3389/fpsyg.2020.00792

Harahap, D. S., \& Khair, H. (2019). Pengaruh Kepemimpinan dan Kompensasi terhadap Kepuasan Kerja Melalui Motivasi Kerja. Maneggio: Jurnal Ilmiah Magister Manajemen, 2(1), 69-88. https://doi.org/10.30596/maneggio.v2i1.3404

Hartini Sri Elisa, S. J. (2017). Pengaruh Konflik Peran dan Kepuasan Kerja terhadap Kinerja Karyawan Tetap pada PT. PLN (Persero) Wilayah Sulsel, Sultra dan Sulbar Area Baubau. Jurnal Ilmu Manajemen (JIM), 5(3), 1-8.

Heffernan, M., \& Dundon, T. (2016). Cross-Level Effects of High-Performance Work Systems (HPWS) and Employee Well-Being: The Mediating Effect of Organisational Justice. Human Resource Management Journal, 26(2), 211-231. https://doi.org/10.1111/1748-8583.12095

Huang, Y., Ma, Z., \& Meng, Y. (2018). High-Performance Work Systems and Employee Engagement: Empirical Evidence from China. Asia Pacific Journal of Human Resources, 56(3), 341-359. https://doi.org/10.1111/1744-7941.12140

Irawati, R., \& Carollina, D. A. (2017). Analisis Pengaruh Beban Kerja terhadap Kinerja Karyawan Operator pada PT Giken Precision Indonesia. Inovbiz: Jurnal Inovasi Bisnis, 5(1), 51. https://doi.org/10.35314/inovbiz.v5i1.171

Juwita, K., \& Arintika, D. (2018). Dampak Konflik Peran terhadap Stres dan Kepuasan Kerja Karyawan PT. Jombang Intermedia Press (Jawa Pos Radar Jombang). Jurnal Manajemen Indonesia, 18(2), 105. https://doi.org/10.25124/jmi.v18i2.1237

Kianto, A., Vanhala, M., \& Heilmann, P. (2016). The Impact of Knowledge Management on Job Satisfaction. Journal of Knowledge Management, 20(4), 621-636. https://doi.org/10.1108/JKM-102015-0398

Kuncoro, W. S., Wulan, H. S., \& Haryono, A. T. (2018). Pengaruh Konflik Kerja , Lingkungan Kerja dan Stres Kerja terhadap Prestasi Kerja ( Kepuasan Kerja sebagai Variabel Intervening ) Di Pt Roberta Prima Tobacco. Journal Of Management, 4(4).

Lukito, L. H., \& Alriani, I. M. (2018). Pengaruh Beban Kerja, Lingkungan Kerja, Stres Kerja terhadap 
Kinerja Karyawan pada PT. Sinarmas Distribusi Nusantara Semarang. Jurnal Ekonomi Manajemen Dan Akuntansi, 25(45), 24-35. http://ejurnal.stiedharmaputrasmg.ac.id/index.php/JEMA/article/view/329

Maoe, V. A., Sintaasih, D. K., \& Sudibya, I. G. A. (2016). Pengaruh Konflik Peran terhadap Kepuasan Kerja dan Kinerja Pendeta Gereja Kristen Protestan di Bali. E-Jurnal Ekonomi Dan Bisnis Universitas Udayana, 5(5), 1279-1308.

Maung, K. M. (2020). The Effects of High Performance Work Systems on Employees in Aged Care. South East Asia Journal Contemporary Business, Economics and Lau, 13(5), 1-17. https://doi.org/10.1080/10301763.2003.10669269

Murtani, A. (2017). Pengaruh Pengembangan Karyawan dan Fasilitas Kerjaterhadap Kepuasan Kerja Karyawan di PT . Bank Sumut Syariah Cabang Medan Alim Murtani Fakultas Bisnis Syariah , Universitas Potensi Utama. Jurnal A-Qasd, 1(2), 177-188.

Nur, I. R., Hidayati, T., \& Maria, S. (2016). Pengaruh Konflik Peran, Ambiguitas Peran dan Stres Kerja terhadap Kinerja Karyawan. Jurnal Manajemen, 8(1), 1-18. https://core.ac.uk/download/pdf/229017687.pdf

Palomino, M. N., \& Frezatti, F. (2016). Role Conflict, Role Ambiguity and Job Satisfaction: Perceptions of The Brazilian Controllers. Revista de Administração, 165-181. https://doi.org/10.5700/rausp1232

Pang, K., \& Lu, C. S. (2018). Organizational Motivation, Employee Job Satisfaction and Organizational Performance: An Empirical Study of Container Shipping Companies in Taiwan. Maritime Business Review, 3(1), 36-52. https://doi.org/10.1108/MABR-03-2018-0007

Rahman, K. U., Akhter, W., \& Khan, S. U. (2017). Factors Affecting Employee Job Satisfaction: A Comparative Study of Conventional and Islamic Insurance. Cogent Business and Management, 4(1), 1-15. https://doi.org/10.1080/23311975.2016.1273082

Rahmatullah, A., \& Siddiqui, D. A. (2019). Impact of High-Performance Work System on Job Satisfaction, Organizational Commitment, Job Complexities and Intention to Quit: A Karachi Based Study on Banking and Education Industry. SSRN Electronic Journal. https://doi.org/10.2139/ssrn.3384162

Ridho, M., \& Susanti, F. (2019). Pengaruh Stres Kerja dan Motivasi Kerja terhadap Kepuasan Kerja pada Karyawan Bank Mandiri Syariah Cabang Padang. INA-Rxiv Papers, 3(2). https://doi.org/10.31227/osf.io/pa2cg

Rovithis, M., Linardakis, M., Rikos, N., Merkouris, A., Patiraki, E., \& Philalithis, A. (2017). Role Conflict and Ambiguity Among Physicians and Nurses in The Public Health Care Sector in Crete. Archives of Hellenic Medicine, 34(5), 648-655.

Sahani. (2016). The Impact of High Performance Work Systems on Employee Job Satisfaction of Executives in Private Sector Commercial Banks in Colombo District. Journal of Chemical Information and Modeling, 1(1), 1689-1699.

Theresia Kusriyani, Maria Magdalena, P. D. P. (2016). Pengaruh Konflik Peran, Kelelahan Emosional dan Kepuasan Kerja terhadap Intensitas Turnover yang Dimediasi Komitmen Organisasi pada 
Alifa Nur Maulidina \& Agus Frianto. Pengaruh High-Performance Work System (HPWS) dan Konflik Peran terhadap Kepuasan Kerja

Dinas Pasar Kota Semarang. Journal Of Management, 02(5), 571-572. https://doi.org/10.4295/audiology.59.571

Widarni, E. L. (2017). Pengaruh Motivasi Kerja, Konflik Peran, dan Kepuasan Kerja terhadap Kinerja Guru di SMP Bahrul Maghfiroh Malang. Jurnal Bisnis Indonesia, 8(2), 6. https://doi.org/10.35457/akuntabilitas.v9i1.205

Widiasari, D. P., \& Budiono. (2016). Pengaruh Konflik Peran dan Pengembangan Karir terhadap Kepuasan Kerja (Studi Pegawai Divisi Konstruksi IV di PT. Adhi Karya (Persero) Tbk. Surabaya. Jurnal Riset Ekonomi Dan Manajemen, 16(1), 44. https://doi.org/10.17970/jrem.16.160104.id

Wulandari, I. S., Frianto, A., Studi, P., Fakultas, M., Universitas, E., Surabaya, N., \& Surabaya, K. (2020). Peran High Performance Work System terhadap Employee Engagement dan Employee Resilience : Studi Literatur. BIMA ; Journal of Business and Innovation Management, 3, 1-16.

Yasa, I. W. M. (2017). Pengaruh Konflik Peran dan Ambiguitas Peran terhadap Kinerja Pegawai Melalui Mediasi Stres Kerja pada Dinas Kesehatan Kota Denpasar Bali. Jurnal Ekonomi Dan Bisnis, 4(1), 38-57. https://doi.org/10.22225/JJ.4.1.203.38-57

Zhang, J., Akhtar, M. N., Bal, P. M., Zhang, Y., \& Talat, U. (2018). How Do High-Performance Work Systems Affect Individual Outcomes: A Multilevel Perspective. Frontiers in Psychology, 9(APR), 1-13. https://doi.org/10.3389/fpsyg.2018.00586 